\title{
The Effect of Different Temperatures and Durations on the Dormancy Breaking of Black Locust (Robinia pseudoacacia L.) and Honey Locust (Gleditsia triacanthos L.) Seeds
}

\author{
Mehmet BASBAG ${ }^{11}$, Ali AYDIN ${ }^{12}$, Davut AYZIT ${ }^{2}$ \\ ${ }^{1)}$ Dicle University, Faculty of Agriculture, Department of Field Crops, 21280, Diyarbakir,Turkey; mbasbag@dicle.edu.tr \\ ${ }^{2)}$ Diyarbakir Provincial Directorate of Environment and Forestry, 21070, Diyarbakir, Turkey
}

\begin{abstract}
In order to break seed dormancy, different temperatures $\left(20,30,40,50,60,70,80\right.$ and $\left.90^{\circ} \mathrm{C}\right)$ and durations $(10,20$ and 30 minutes) were applied to black locust (Robinia pseudoacacia L.) and honey locust (Gleditsia triacanthos L.) seeds, in the Seed Laboratory of Dicle University - Faculty of Agriculture in 2009. According to the research results, the highest germination rate for black locust seeds was obtained in the case of $90^{\circ} \mathrm{C}$ for 30 minutes pre-treatment $(94.5 \%)$, whilst the lowest value was obtained for the $40^{\circ} \mathrm{C}$ for 10 minutes pretreatment (7.5.0\%). For honey locust the highest value was obtained at $50^{\circ} \mathrm{C}$ for 30 minutes $(25.5 \%)$ and the lowest value was obtained in the case of control sample $(6.8 \%)$.
\end{abstract}

Keywords: black locust, honey locust, dormancy breaking, seeds

\section{Introduction}

Black locust (Robinia pseudoacacia L.) and honey locust (Gleditsia triacanthos L.) originated from North America and were spread to large areas throughout the world for various purposes (Cronk and Fuller, 1995; Singh et al., 1991). These species are legume trees which are drought resistant, light lover, thorny and show moderate to fast growth speed (Danso et al., 1995; Burner et al., 2005). The wood of these species has various utilizations: firewood, sawn timber, poles for fences, wind-breaking, erosion control, forage crops and the species are important in beekeeping (Burner et al., 2005; Singh et al., 1991; Sefik, 1995).

In general, the production of black locust $(R$. pseudoacacia L.) and honey locust ( $G$. triacanthos L.) is from seeds. Without pre-treatments seed germination rate is low because of the physiological dormancy induced by the hard seed coats (Geneve, 2008, Singh et al., 1991). In order to increase germination rate, various heating pre-treatments are applied: Masaka and Yamada (2009) obtained the highest germination rates $(45.3 \%)$ for their heat shock application to black locust seeds by keeping them at $60^{\circ} \mathrm{C}$ for 3 hours. Bolin (2009) in his heat applications to Galactia regularis (Fabaceae), Lupinusperennis (Fabaceae) and Rhus copallinum seeds, obtained the highest germination values by keeping the seeds at $80^{\circ} \mathrm{C}(G$. regularis and $L$. perennis $)$ and $90^{\circ} \mathrm{C}$ ( $R$. copallinum) for 10 minutes. Khadduri et al. (2002), by soaking black locust ( $R$. pseudoacacia) seeds in hot water $\left(98^{\circ} \mathrm{C}\right)$ for 24 hours, achieved $41 \%$ germination rate. Basbag et al. (2009) have obtained seed germination rates between 8.39 and $29.52 \%$ for caper (Capparis ovata) seeds by applying different temperatures and durations.

The aim of this study is to assess the increase in the germination rates of black locust and honey locust seeds by applying pre-germination treatments of different durations and temperatures.

\section{Materials and methods}

The study was performed in 2009 in Dicle University - Faculty of Agriculture Seed Laboratory. Black locust $(R$. pseudoacacia) and honey locust ( $G$. triacanthos) seeds were collected from trees within the campus of Dicle University (elevation: $700 \mathrm{~m}$, latitude: N37 $55^{\prime} 27.3^{\prime \prime}$ and longitude: $\left.\mathrm{E} 40^{\circ} 17^{\prime} 05.1^{\prime \prime}\right)$, on the $21^{\text {st }}$ of November 2009 . Seeds separated from pods were washed in water and empty, puny ones were removed. The weight of 1000 seeds was $15.6 \mathrm{~g}$ for black locust and $165.7 \mathrm{~g}$ for honey locust.

In order to break dormancy, seeds were kept within the drying cabinet (ULM-800) in different temperature environments $\left(20,30,40,50,60,70,80\right.$ and $\left.90^{\circ} \mathrm{C}\right)$ and for different durations (10, 20 and $30 \mathrm{~min}$.). Germination experiments were performed in Petri dishes (using paper towels and distilled water) and for each treatment 50 seeds were used with 4 replications. The Petri dishes were placed in a germination cabinet (Growth Chamber, GC 400), at $25^{\circ} \mathrm{C}$ temperature and $70 \%$ humidity, and the cabinet was programmed to be under light for 12 hours (flourescent, 1500 Lux) and 12 hours under darkness. The 4 replications of the no-pretreatment control sample were placed in the germination cabinet, under the same conditions. The ger- 
126

minated seeds were counted periodically starting from the $7^{\text {th }}$ day until the $30^{\text {th }}$ day. Germination percentage (\%) was calculated according to the below formula (Pieper, 1952);

$$
\mathrm{GR}=\frac{(\mathrm{n} 1 \times \mathrm{t} 1)+(\mathrm{n} 2 \times \mathrm{t} 2)+(\mathrm{n} 3 \times \mathrm{t} 3)+(\mathrm{ni} \times \mathrm{ti})}{\mathrm{T}}
$$

GR: Germination (\%)

ni: Number of count days

ti: Number of germinated seeds at each count

$\mathrm{T}$ : Total number of germinated seeds

The germination values for each pre-treatment were compared, after angle transformation (Zar, 1999) with MSTATC statistical package software (Michigan State University, East Lansing, MI) according to the Randomised Blocks Design.

\section{Results and discussion}

Different temperatures and different durations of the pre-germination treatments applied to black locust (Robinia pseudoacacia L.) and honey locust (Gleditsia triacanthos L.) seeds had a statistically different effect on seed germination (Tab. 1 and 2). For black locust seeds, the average germination values varied between $7.5 \%$ and $71.8 \%$, according to the different temperatures applied during the pre-germination treatment. The highest rate of germination was obtained at $90^{\circ} \mathrm{C}$ and the lowest rate was obtained for the control sample (no treatment). Considering the dual effect of temperature and duration the germination values varied between $7.5 \%$ and $94.5 \%$.The highest germination value was obtained at $90^{\circ} \mathrm{C}$ and 20 minutes duration, whilst the lowest germination value was obtained for the control sample (7.5\%).

For honey locust seeds, the average germination values varied between $6.8 \%$ and $19.3 \%$, according to the different temperatures applied. The highest percentage of germina-
Tab. 1. The effect of different temperatures and durations on germination rates of black locust (Robinia pseudoacacia L.) seeds

\begin{tabular}{|c|c|c|c|c|c|c|c|}
\hline \multicolumn{8}{|c|}{ Black locust (R. pseudoacacia L.) } \\
\hline \multirow{2}{*}{$\begin{array}{c}\text { Temperature } \\
\left({ }^{\circ} \mathrm{C}\right)\end{array}$} & \multicolumn{6}{|c|}{ Duration (minute) } & \multirow{2}{*}{ Mean } \\
\hline & \multicolumn{2}{|c|}{10} & \multicolumn{2}{|c|}{20} & \multicolumn{2}{|c|}{30} & \\
\hline Control & 7.5 & $\mathrm{jk}$ & 7.5 & $\mathrm{jk}$ & 7.5 & $\mathrm{jk}$ & 7.5 \\
\hline 20 & 11.5 & $h-j$ & 15.0 & $h-j$ & 15.5 & $g-1$ & 14.0 \\
\hline 30 & 11.5 & j & 12.0 & j & 13.5 & $h-j$ & 12.3 \\
\hline 40 & 9.5 & $\mathrm{k}$ & 12.0 & $1-j$ & 11.5 & $1-j$ & 11.0 \\
\hline 50 & 27.0 & c & 33.5 & $\mathrm{~b}$ & 21.0 & de & 27.2 \\
\hline 60 & 22.5 & de & 20.5 & fg & 23.5 & $\mathrm{~d}$ & 22.2 \\
\hline 70 & 15.5 & $h-j$ & 17.5 & f-h & 16.5 & $\mathrm{f}$ & 16.5 \\
\hline 80 & 16.5 & fg & 19.0 & $\mathrm{e}$ & 32.5 & $\mathrm{~b}$ & 22.7 \\
\hline 90 & 30.5 & c & 94.5 & a & 90.5 & a & 71.8 \\
\hline Average & 16.9 & & 25.7 & & 25.8 & & \\
\hline $\operatorname{LSD}(\mathrm{p}<0.05)$ & & & & 2. & & & \\
\hline $\mathrm{CV}$ & & & & 5.5 & & & \\
\hline
\end{tabular}

Tab. 2. The effect of different temperatures and durations on germination rates of honey locust (Gleditsia triacanthos L.) seeds

\begin{tabular}{|c|c|c|c|c|c|c|c|}
\hline \multicolumn{8}{|c|}{ Honey locust (G. triacanthos L.) } \\
\hline \multirow{2}{*}{$\begin{array}{c}\text { Temperature } \\
\left({ }^{\circ} \mathrm{C}\right)\end{array}$} & \multicolumn{6}{|c|}{ Duration (minute) } & \multirow{2}{*}{ Mean } \\
\hline & \multicolumn{2}{|c|}{10} & \multicolumn{2}{|c|}{20} & \multicolumn{2}{|c|}{30} & \\
\hline Control & 6.8 & o & 6.8 & o & 6.8 & o & 6.8 \\
\hline 20 & 12.0 & h-l & 13.0 & $g-j$ & 13.5 & $e-h$ & 12.8 \\
\hline 30 & 14.0 & $g-j$ & 14.5 & $f-1$ & 18.5 & $b-d$ & 15.7 \\
\hline 40 & 10.5 & no & 13.5 & $c-f$ & 20.0 & bc & 14.7 \\
\hline 50 & 15.0 & $g-k$ & 17.3 & $d-g$ & 25.5 & a & 19.3 \\
\hline 60 & 17.0 & $c-f$ & 18.0 & c-e & 19.5 & $\mathrm{ab}$ & 18.2 \\
\hline 70 & 11.0 & $1-1$ & 9.5 & $j-m$ & 11.5 & $\mathrm{~g}-\mathrm{k}$ & 10.7 \\
\hline 80 & 10.0 & $1-n$ & 11.5 & $j-m$ & 9.5 & $\mathrm{k}-\mathrm{n}$ & 10.3 \\
\hline 90 & 8.0 & no & 9.3 & $m-n$ & 13.5 & $g-j$ & 10.3 \\
\hline Average & 11.6 & & 12.6 & & 15.4 & & \\
\hline $\operatorname{LSD}(p<0.05)$ & & & & & & & \\
\hline $\mathrm{CV}$ & & & & 8. & & & \\
\hline
\end{tabular}

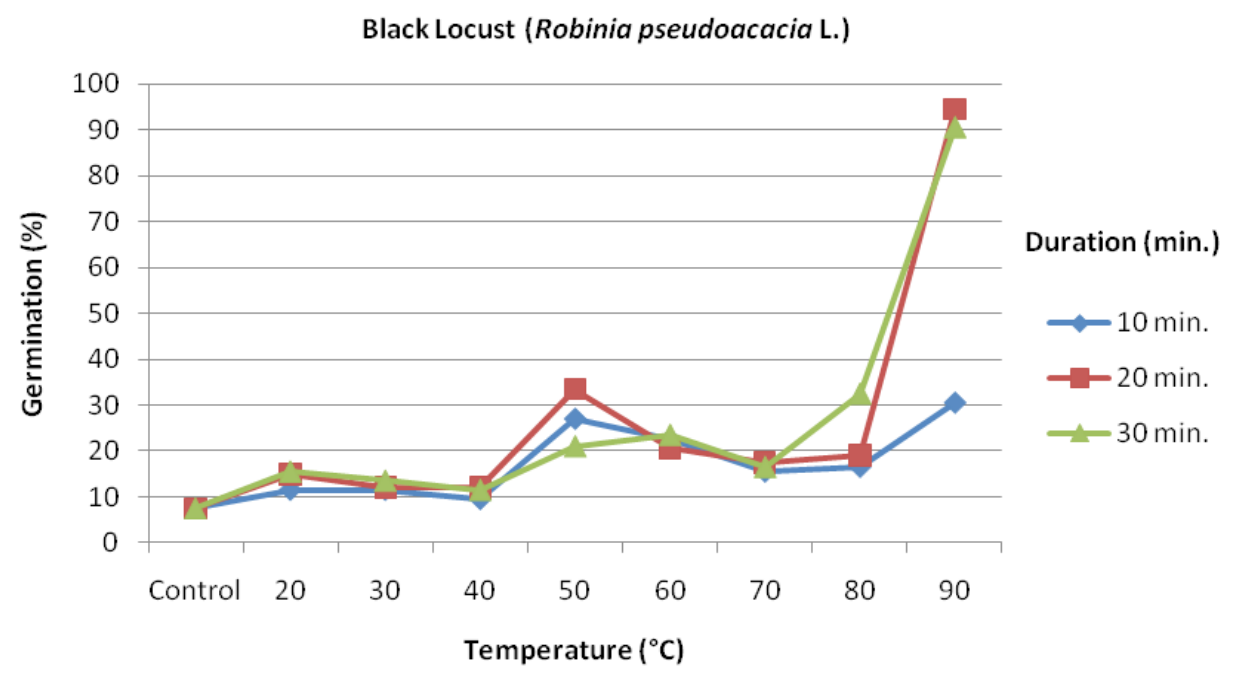

Fig. 1. The effect of different temperatures and durations on germination rates of black locust (Robinia pseudoacacia L.) seeds 


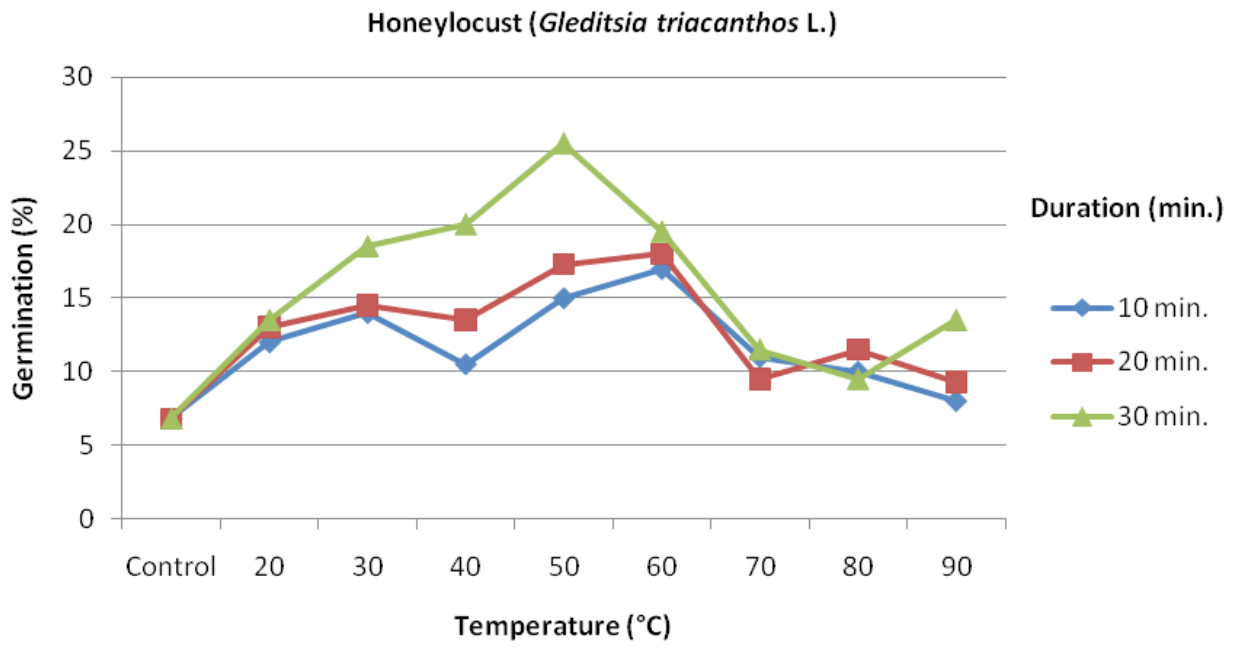

Fig. 2. The effect of different temperatures and durations on germination rates of honey locust (Gleditsia triacanthos L.) seeds

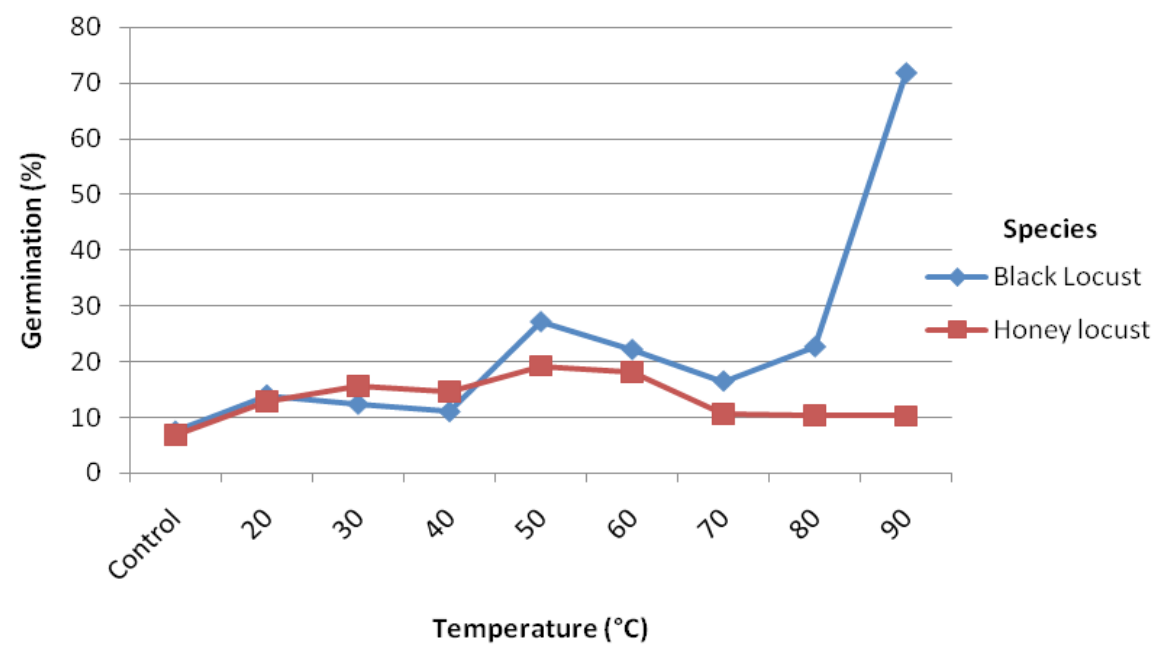

Fig. 3. The effect of different temperatures and durations on germination rates of black locust (Robinia pseudoacacia L.) and honey locust (Gleditsia triacanthos L.) seeds

tion was obtained at $50^{\circ} \mathrm{C}$ and the lowest percentage was obtained when no pre-germination treatment was applied. The germination values varied between $6.8 \%$ and $25.5 \%$ when both temperature and duration were considered. The highest germination value was obtained at $90^{\circ} \mathrm{C}$ and 30 minutes of duration; the lowest germination value was obtained for the control sample.

\section{Conclusions}

Despite the fact that there are no published studies in the region on the same species, relatively similar results to our findings were obtained in similar studies undertaken for different species of the same family (Bowen and Eusebio, 1981; Bolin, 2009) and on different species of different families (Basbag et al., 2009).

\section{References}

Basbag, M., O. Toncer and S. Basbag (2009). Effects of different temperatures and duration on germination of caper (Capparis ovata) seeds. Journal of Environmental Biology 30(4)621-624.

Bolin, J. F. (2009). Heat Shock Germination Responses of Three Eastern North American Temperate Species. Castanea $74(2): 160-167$.

Bowen, M. R. and T. V.Eusibio (1981). Acacia mangium updated information on seed collection, handling and germination testing. Occasional Tech. and Scientific Notes, Seed Series No. 5, Forest Research Centre, Sepilok, Sabah. Erişim: FAO, Food And Agriculture Organızation of The United Nations. A Guide to Forest Seed Handling.

Burner, D. M., D. H. Pote1 and A. Ares (2005). Management 
128

effects on biomass and foliar nutritive value of Robinia pseudoacacia and Gleditsia triacanthos f. inermis in Arkansas, USA. Agroforestry Systems 65:207-214.

Cronk, Q. C. B. and J. L. Fuller (1995). Plant invaders: the threat to natural ecosystems. Chapman and Hall, London.

Danso S. K. A., F. Zapata and K. O. Awonaike (1995). Measurement of biological $\mathrm{N}_{2}$ fixation in field-grown Robinia pseudoacacia L. Soil Biol. Biochem. 27:415-419.

Geneve, R. L. (2008). A Closer Look at Seed Germination and Dormancy. Department of Horticulture University of Kentucky, Lexington, Kentucky 40546. http://www.ipps. org/SouthernNA/pdf/2008papers/Geneve-Bob.pdf.

Khadduri, N. Y., J. T. Harrington, L. S. Rosner and D. R. Dreesen (2002). Percussion as an alternative scarification for New Mexico Locust and Black Locust seed, 309-316 pp. In: National proceedings: forest and conservation nursery associations-1999, 2000, and 2001. Proceedings RMRSP-24. Ogden, UT: U.S. Department of Agriculture Forest Service, Rocky Mountain Research Station.

Masaka, K. and K. Yamada (2009). Variation in germination character of Robinia pseudoacacia L.(Leguminosae) seeds at individual tree level. Journal of Forest Research 14:16-177.

Sefik, Y. (1995). Agroforestry. Karadeniz Technical University, Faculty of Forestry Pubs. No. 176/21, Trabzon, Turkey.

Singh, D. P., M. S. Hooda and F. T. Bonner (1991). An evaluation of scarification methods for seeds of two leguminous trees. New Forests 5(2):67-173.

Sozzi, G. and A. Chiesa (1995). Improvement of caper (Capparis spinosa L.) seed germination by breaking seed coat-induced dormancy. Scientia Horticulturae 62:255-261.

Zar, J. H. (1999). Biostatistical Analysis. Fourth Edition. Prentice Hall, Upper Saddle River, New Jersey. 